\author{
Military Technical College \\ Kobry El-Kobbah, \\ Cairo, Egypt
}

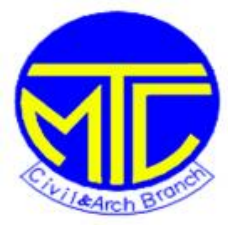

$9^{\text {th }}$ International Conference
on Civil and Architecture
Engineering
ICCAE-9-2012

\title{
New Concrete Admixtures for Improved the Mechanical Properties of Concrete
}

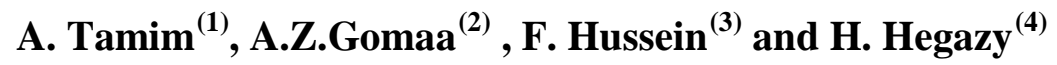

\begin{abstract}
The reaction product of linseed oil fatty acid and diethano 1 amine was used as a concrete admixture. It has multiple benefits; it reduces the required water content for a concrete mixture by about $13 \%$ (by adding admixture equal $0.1 \%$ of cement content) and also slows the corrosion of reinforcing steel in concrete. By reducing the water / cement ratio a higher compressive strength is produced without increasing the amount of cement. It acts as an accelerating admixture which reduces initial and final setting time rate of concrete. Also it can be used as corrosion inhibitor which imparts a defensive strategy for concrete structures in marine atmosphere, high way bridges and others.

This admixture is classified as F group according to ASTM C 494. In the present study, the authors will concentrate on the effect of the admixture on improving the mechanical properties of concrete. The comparison of the new admixture and a commercial one on the concrete properties showed that, this admixture improved mechanical properties by about $20 \%$ more than commercial admixture.
\end{abstract}

Keywords: concrete, mechanical properties, concrete admixture.

\section{1- Introduction}

Chemical admixtures are some ingredients that added to concrete other than portland cement, water, and aggregate which are added to the mix immediately during mixing.

Producers use admixtures primarily to reduce the cost of concrete construction, to modify the properties of hardened concrete, to ensure the quality of concrete during mixing, transporting, placing, curing, and to overcome certain emergencies during concrete operations $^{(1)}$.

Admixtures are classified according to their function. There are five distinct classes of chemical admixtures: air-entraining, water-reducing, retarding, accelerating, and plasticizers

(1) Mechanical Department, High Institute of Engineering, 15 May City.

(2) Consultant, Email: gomoa11@yahoo.com.

(3) Civil Engineering Department, High Institute of Engineering, 15 May City.

(4)_ Physical Chemistry Department, National Research Center. 
(super plasticizers) ${ }^{(2,3)}$. All other varieties of admixtures fall into the specialty category where these functions include corrosion inhibition, shrinkage reduction, alkali -silica reactivity reduction, workability enhancement, bonding, damp proofing, and coloring. In the following a short summary of the main class es of the chemical admixtures:-

- Air-entraining admixtures: Air-entraining agents enter small air bubbles in the concrete. The major benefit of this is enhanced durability in freeze -thaw cycles, especially relevant in cold climates.

- Water-reducing admixtures usually reduce the required water content for a concrete mixture by about 5 to 10 percent. Consequently, concrete containing a water-reducing admixture needs less water to reach a required slump than untreated concrete. Water reducers are mostly used for hot weather concrete placing and to aid pumping.

- Retarding admixtures: which slow the setting rate of concrete, they are used to counteract the accelerating effect of hot weather on concrete setting. Retarders keep concrete workable during placement and delay the initial set of concrete.

- Accelerating admixtures increase the rate of early strength development, reduce the time required for proper curing and protection, and speed up the start of finishing operations.

- Superplasticizers, or high-range water reducers (HRWR), reduce water content by 12 to 30 percent and can be added to concrete to make high -slump flowing concrete.

Usually fatty acids are added to cement to work as inhibitor. Also fatty acid is used to prevent the pieces from agglomerat ing. The commercial accelerating admixtures depends mainly on calcium chloride however, it causes corrosion of impeded reinforced steel $^{(4)}$.

\section{2- Materials:}

2-1 The cement

The used cement was $32.5 \mathrm{~N}$ that complies with the requirement of the Egypt ian Standard Specifications (ESS 4756-1/2007) ${ }^{(5)}$, and was

Supplied from National Company for cement ${ }^{(6)}$.Table (1) illustrates the analysis of cement used in this study.

Table (1) Analysis of cement used.

\begin{tabular}{|l|l|}
\hline Compositions & \multicolumn{1}{c|}{ Percentage (\%) } \\
\hline $\mathrm{SiO} 2$ & $20.5-21.5$ \\
\hline $\mathrm{Al}_{2} \mathrm{O}_{3}$ & $5.0-6.0$ \\
\hline $\mathrm{Fe}_{2} \mathrm{O}_{3}$ & $3.5-2.5$ \\
\hline $\mathrm{CaO}$ & $62.5-63.5$ \\
\hline $\mathrm{MgO}$ & Less than 2.5 \\
\hline $\mathrm{Na}_{2} \mathrm{O}+\mathrm{K}_{2} \mathrm{O}$ & Less than 0.6 \\
\hline $\mathrm{SO}_{3}$ & Less than 3.5 \\
\hline $\mathrm{Cl}$ & Less than $1 \%$ \\
\hline
\end{tabular}




\begin{tabular}{|l|l|}
\hline L.O.I (loss on ignition) & Less than $5.0 \%$ \\
\hline Blaine surface area & $2800-3200 \mathrm{~cm}^{2} / \mathrm{gm}$ \\
\hline
\end{tabular}

2-2 The coarse aggregates were crushed stones with two

sizes $\mathrm{S} 1$ (0.15 to $5 \mathrm{~mm}$ particle size) and $\mathrm{S} 2$ (5 to $38.1 \mathrm{~mm}$ particle size). Table (2) shows the sieve analysis test results for the used fine and coarse aggregates (size $\mathrm{S} 1$ and size $\mathrm{S} 2)^{(7)}$

Table (2) Sieve analysis test results for fine and coarse aggregate

\begin{tabular}{|c|l|l|l|l|l|l|l|}
\hline $\begin{array}{c}\text { Fine } \\
\text { Aggregate } \\
\text { size S1 }\end{array}$ & $\begin{array}{l}\text { Sieve } \\
\text { size(mm) }\end{array}$ & 5 & 2.36 & 1.18 & 0.6 & 0.3 & 0.15 \\
\cline { 2 - 8 } & $\%$ passing & 100 & 96.6 & 80.8 & 51.1 & 24.3 & 0.6 \\
\hline $\begin{array}{c}\text { Coarse } \\
\text { Aggregate } \\
\text { size S2 }\end{array}$ & $\begin{array}{l}\text { Sieve } \\
\text { size(mm) }\end{array}$ & 38.1 & 31.5 & 28.0 & 20.0 & 10.0 & 5 \\
\cline { 2 - 8 } & $\%$ passing & 100 & 100 & 96.3 & 88.7 & 20.2 & 0.7 \\
\hline
\end{tabular}

Table (3) illustrates the physical properties of the used crushed stone (size S1 and S2) ${ }^{(8)}$. Table (3) properties of crushed stone(Fine and Coarse Aggregates)

\begin{tabular}{|l|c|c|}
\hline \multicolumn{1}{|c|}{ Property } & Fine Agg.S1 & Coarse Agg.S2 \\
\hline Specific gravity & 2.63 & 2.5 \\
\hline Volumetric weight $\left(\mathrm{t} / \mathrm{m}^{3}\right)$ & 1.595 & 1.64 \\
\hline Crushing value & - & $15.67 \%$ \\
\hline \% fine materials(by weight) & 2.56 & - \\
\hline
\end{tabular}

\section{3-Experimental Work:}

\section{3-1 Introduction}

The experimental program of this study investigates the effect of adding the new admixture based on diethanol amine and fatty acid and commercial admixture at different dosages to the concrete mixture. Concrete properties are widely varied depending upon many factors; the strength level required, test age, material characteristic, and type of application. The tests have applied on the concrete in two cases fresh concrete and hard concrete. The tests for fresh concrete are setting time, worka bility and reduction of water - cement ratio according Egyptian Standard Specifications (ESS 4756-1/2007). The main test for hard concrete is the compressive strength level with test age. The shape of compressive strength sample is a cube with dimension of $15 \mathrm{~cm} \times 15 \mathrm{cmx} 15 \mathrm{~cm}$. The compressive strength was measured after 3,7 and 28 days. The concrete mix was designed to give a cube compressive strength of $350 \mathrm{~kg} / \mathrm{cm}^{2}$ after 28 days. Table (4) illustrates the mix proportions (by weight) for one cubic meter of con crete ${ }^{(9)}$. All tests were repeated on commercial admixture, which under the same conditions.

Table (4) Mix Proportions per cubic Meter of concrete

\begin{tabular}{|c|c|c|c|c|}
\hline Cement (OPC) (kg) & $\begin{array}{c}\text { Sand(S1) } \\
(\mathrm{kg})\end{array}$ & $\begin{array}{c}\text { Coarse Agg.(S2) } \\
(\mathrm{kg})\end{array}$ & $\begin{array}{c}\text { Water } \\
(\text { liters })\end{array}$ & W/C \\
\hline 350 & 640 & 1280 & 175 & 0.50 \\
\hline
\end{tabular}




\section{3-2 Concrete admixture}

The used admixture was prepared in laboratory as amine component based on diethanol amine and fatty acid. This new admixture is called (T1).

\section{3-3 Testing}

The following tests have been carried out according to the Requirement of (ASTM C-494) ${ }^{(10)}$ : Setting time, Workability, Reduction of Water- cement ratio and Compressive strength.

\section{4- Results and Discussion:}

4-1 Results of setting time

a- The results of initial setting time were shown in the Table (5) and Fig (1), where the relation between initial setting time and percentage of admixtures $\mathrm{T} 1$ and commercial (control).

Table ( 5 ) Relation between initial setting time and percentage of admixtures $\mathrm{T} 1$ and commercial ( control).

\begin{tabular}{|c|c|c|}
\hline percentage of admixture & \multicolumn{2}{|c|}{ Initial setting time(minutes) } \\
\cline { 2 - 3 }$\%$ & T1 & commercial \\
\hline 0.00 & 80 & 80 \\
\hline 0.10 & 60 & 50 \\
\hline 0.25 & 50 & 42 \\
\hline 0.50 & 35 & 29 \\
\hline
\end{tabular}

Adding ( 0.1 to $0.5 \%)$ of the admixture T 1 reduces the initial setting time by $20 \%$.

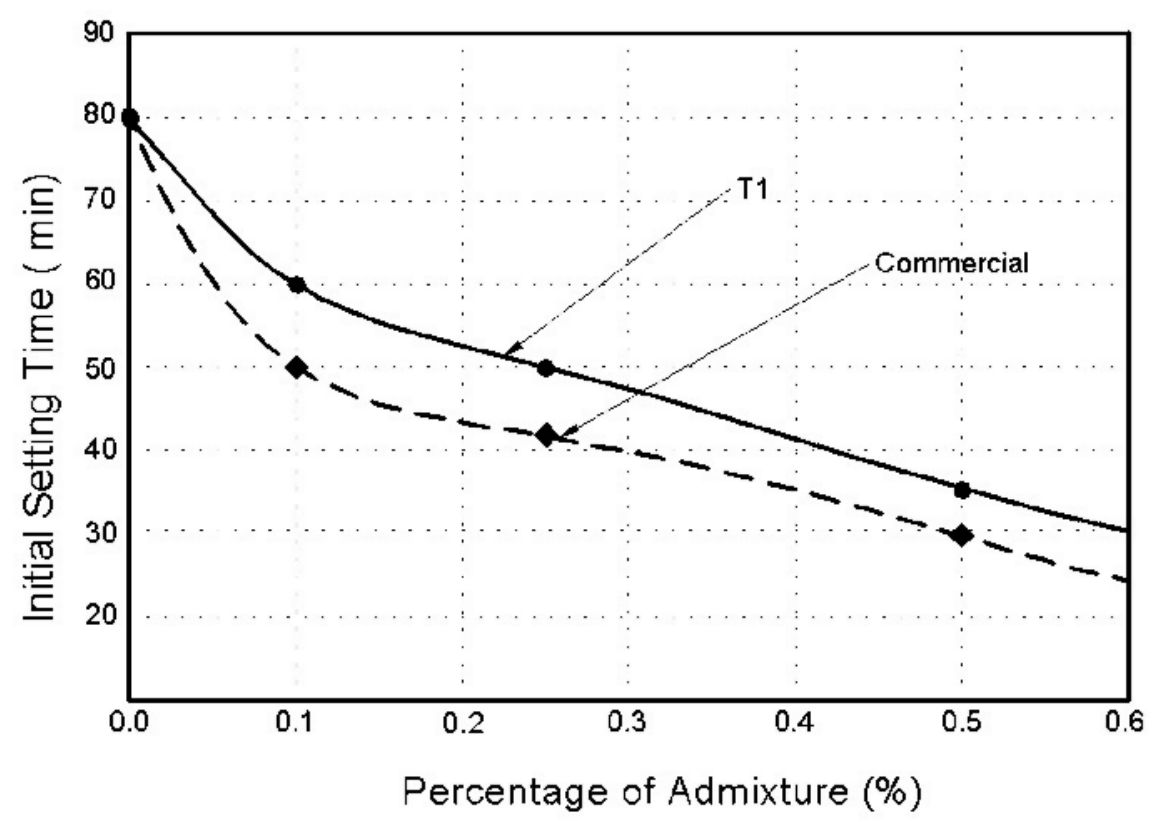


Fig(1) Relation between initial setting time and pe rcentage of admixtures (T1 and commercial).

According to these results, the initial setting time is decreased with increasing the percentage of $\mathrm{T} 1$ and commercial admixture in concrete mixture. This means that, the admixture $\mathrm{T} 1$ is accelerating the initial setting time.

b- The results of final setting time were shown in the Table (6) and Fig (2), where the relation between final setting time and percentage of admixtures $\mathrm{T} 1$ and commercial (control).

Table (6) Relation between final setting time and percentage of admixtures $\mathrm{T} 1$ and commercial (control).

\begin{tabular}{|c|c|c|}
\hline percentage of admixtures & \multicolumn{2}{|c|}{ final setting time(hours) } \\
\cline { 2 - 3 }$\%$ & T1 & commercial \\
\hline 0.00 & 8 & 8 \\
\hline 0.10 & 5.5 & 4.5 \\
\hline 0.25 & 4.4 & 3.7 \\
\hline 0.50 & 2.8 & 2.3 \\
\hline
\end{tabular}

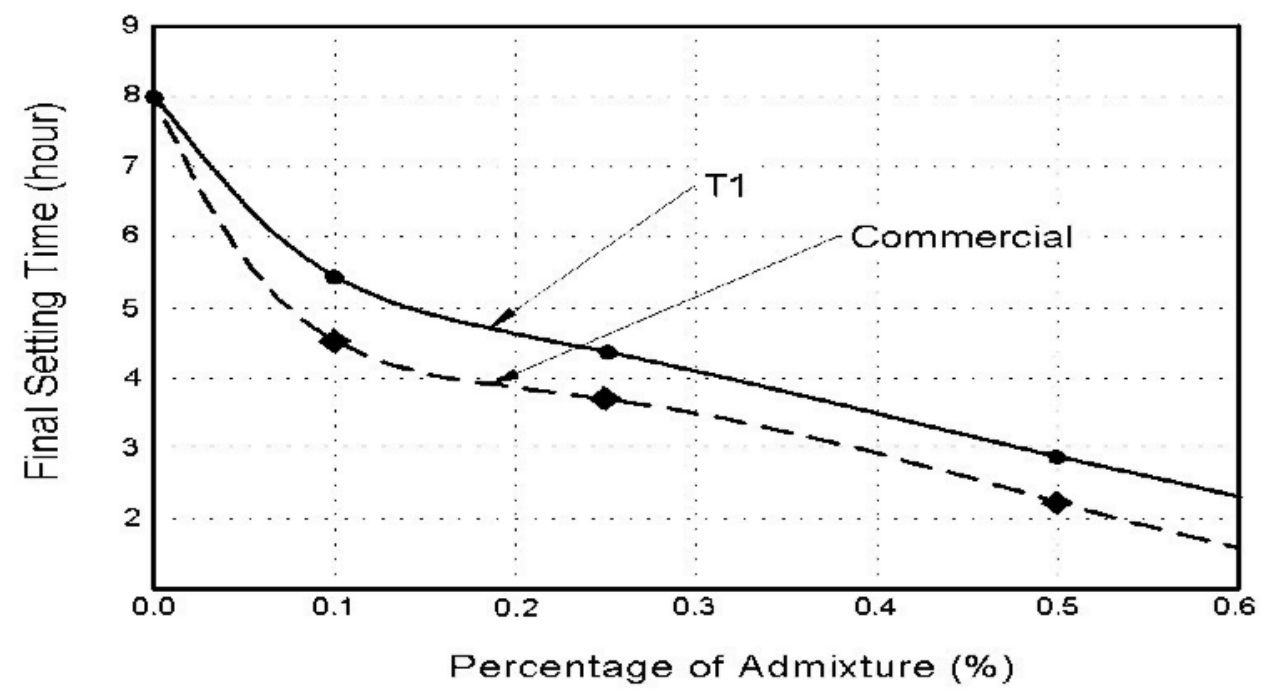

Fig.(2) Relation between final setting time and percentage of admixtures $\mathrm{T} 1$ and commercial.

Adding ( 0.1 to $0.5 \%)$ of the admixture T1 reduces the initial setting time by $20 \%$. The same effect of admixture $\mathrm{T} 1$ on final setting time. The increasing of percentage of $\mathrm{T} 1$ and commercial admixtures are accelerating the final setting time of concrete mixtures .

4-2 Results of workability (slump):

The values of slump were measured when the water quantity in concrete was reduced by values beginning by $5 \%$ to $12 \%$ of initial quantity of water. The values of slump must 
not be exceeding the control slump. Table (7) shows the results of slump value for $0.1 \%$ to $0.75 \%$ admixtures $\mathrm{T} 1$ and commercial additions:

Table (7) Slump values at different percentage admixtureT 1 and commercial admixture .

\begin{tabular}{|c|c|c|c|}
\hline Sample & percentage of admixture & $\begin{array}{c}\text { Slump value } \\
\text { T1 }(\mathrm{cm})\end{array}$ & $\begin{array}{c}\text { Slump value } \\
\text { commercial }\end{array}$ \\
\hline 1 & 0.00 & 8.5 & 8.5 \\
\hline 2 & 0.10 & 8.0 & 7.8 \\
\hline 3 & 0.25 & 7.7 & 7.5 \\
\hline 4 & 0.50 & 7,1 & 7.0 \\
\hline 5 & 0.75 & 6,5 & 6.4 \\
\hline
\end{tabular}

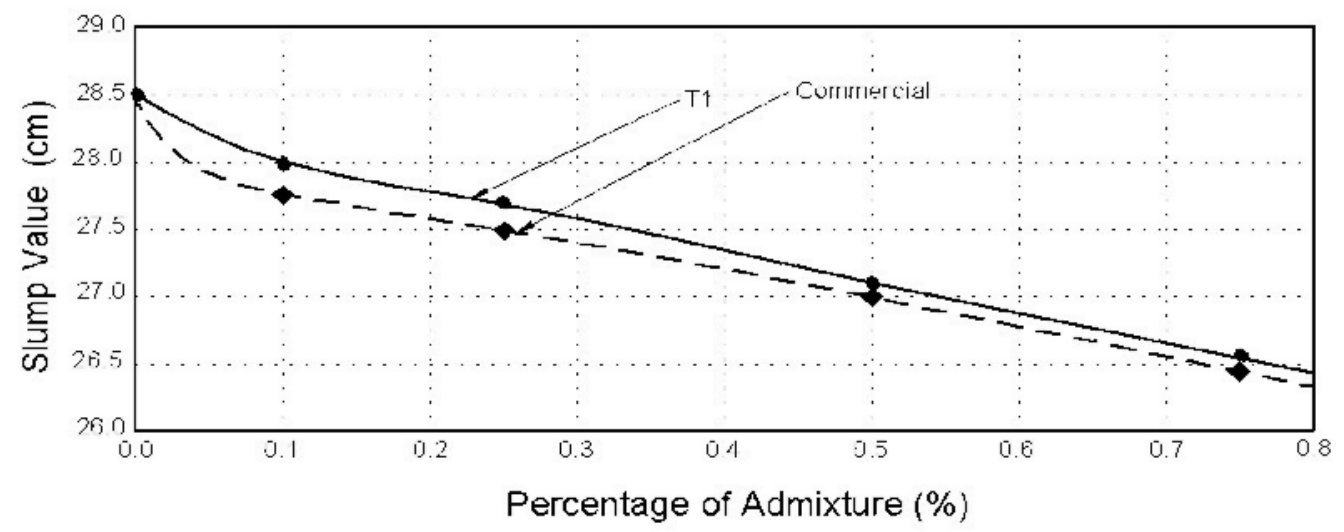

Fig.3 Relation between slump value and percentage of admixture .

As shown in Fig. 3 increasing the admixture of $\mathrm{T} 1$ and commercial percentage helps in increasing the slump value and decrease water/cement ratio which improves concrete properties.

\section{4-3 Results of reduction of water - cement ratio.}

The relation of slump values and reduction in water - cement ratios for different values of $\mathrm{T} 1$ and commercial admixtures are shown in Table (8). For each admixture additions the water - cement ratio was decreased till arrive to the reference slump value ( slump value without additions). Table (8) shows that admixture addition percentage from $0.1 \%$ to $0.75 \%$ lead to decreasing in water - cement ratio by values greater than $12 \%$. The smallest value satisfies the required condition was $0.1 \%$ admixtureT1 or commercial. The commercial admixture have the same effect as T1. 
Table (8) Relation between slump values and percentage of reduction of water - cement ratio at different values of $\mathrm{T} 1$ and commercial admixtures.

\begin{tabular}{|c|c|c|c|c|}
\hline \multirow[t]{2}{*}{ Sample } & \multirow[t]{2}{*}{ percentage of admixture $\mathrm{T} 1, \%$} & \multicolumn{2}{|c|}{ Slump value $(\mathrm{cm})$} & \multirow{2}{*}{$\begin{array}{l}\text { Percentage of } \\
\text { reduction of water- } \\
\text { cement ratio, } \%\end{array}$} \\
\hline & & $\mathrm{T} 1$ & commercial & \\
\hline 1 & 0.00 & 8.5 & 8.5 & \\
\hline \multirow[t]{2}{*}{2} & \multirow[t]{2}{*}{0.10} & 8.1 & 7.9 & 5 \\
\hline & & 8.4 & 8.2 & 13 \\
\hline \multirow[t]{2}{*}{3} & \multirow[t]{2}{*}{0.25} & 8.2 & 8.0 & 5 \\
\hline & & 8.4 & 8.2 & 13 \\
\hline \multirow[t]{4}{*}{4} & \multirow[t]{4}{*}{0.50} & 7.4 & 7.2 & 5 \\
\hline & & 7.5 & 7.4 & 13 \\
\hline & & 7.8 & 7.7 & 15 \\
\hline & & 8.2 & 8.1 & 25 \\
\hline \multirow[t]{4}{*}{5} & \multirow[t]{4}{*}{0.75} & 6.8 & 6.7 & 5 \\
\hline & & 7.4 & 7.3 & 13 \\
\hline & & 7.8 & 7.7 & 20 \\
\hline & & 8.4 & 8.3 & 30 \\
\hline
\end{tabular}

From this table, the reduction of water reaches to $13 \%$ by adding admixture $\mathrm{T} 1$ equal to $0.1 \%$ of cement weight. This means that this type of admixtureT 1 can be categorized as group F (according to ASTM-C494). As the percentage of admixture T1 increase to $0.75 \%$ of cement weight, the percentage of reduction of water reaches to $30 \%$. From these results it can be shown that increasing the percentag e of admixture $\mathrm{T} 1$ in concrete leads to increasing in percentage of reduction of water. This means that this admixtureT 1 can be used as super-plasticizers. The commercial admixture have the same effect as T1.

It can be concluded that:

1- The slump decreases as the percentage of admixture increases for constant reduction in $\mathrm{w} / \mathrm{c}$ ratio.

2- The slump increases as the reduction in w/c ratio increases for constant percentage of admixture.

\section{4-4 Results of compressive strength}

The impact of adding different ratios of a dmixture 11 to concrete mixture on compressive strength after 3days, 7days and 28days is shown in Table (9).

Table (9) Relation between compressive strength and different percentages of admixture $\mathrm{T} 1$.

\begin{tabular}{l|l} 
Percentage of & Compressive strength $\left(\mathrm{kg} / \mathrm{cm}^{2}\right)$
\end{tabular}




\begin{tabular}{|c|c|c|c|c|c|c|}
\hline \multirow{2}{*}{ admixture \% } & \multicolumn{2}{|c|}{3 days } & \multicolumn{2}{c|}{7 days } & \multicolumn{2}{c|}{28 days } \\
\cline { 2 - 7 } & T1 & commercial & T1 & commercial & T1 & commercial \\
\hline 0.00 & 160 & 160 & 204 & 204 & 350 & 350 \\
\hline 0.10 & 203 & 196 & 240 & 234 & 385 & 379 \\
\hline 0.25 & 216 & 205 & 254 & 244 & 394 & 385 \\
\hline 0.50 & 230 & 215 & 268 & 254 & 405 & 393 \\
\hline 0.75 & 245 & 229 & 281 & 266 & 421 & 406 \\
\hline
\end{tabular}

Fig.(4) shows the results of compressive strength at different ages with respect to values of control sample, (commercial and T1 admixtures) values (from $0.1 \%$ to $0.75 \%$ of cement weight)

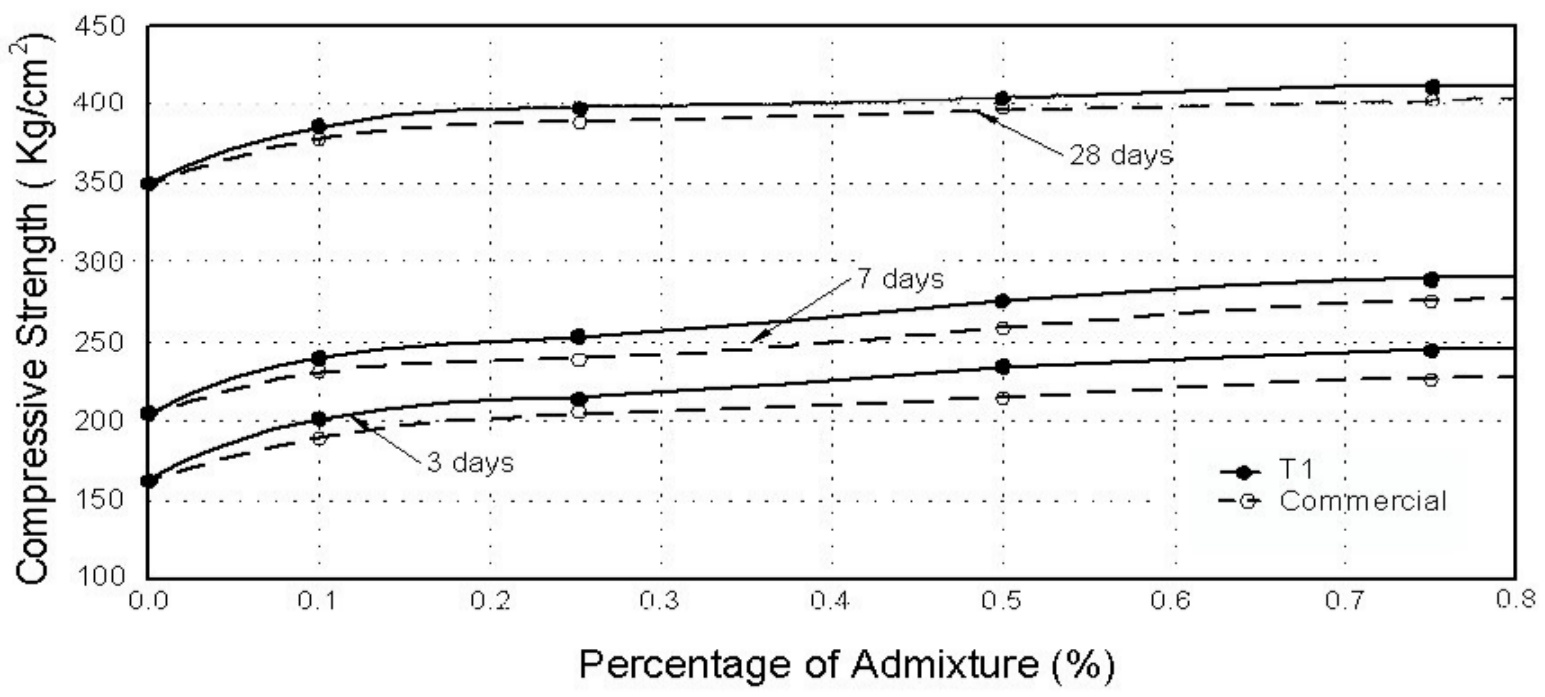

Fig 4: Relation between compression strength and percentage of admixture

4-4 Results of compressive strength and reduction of water/cement $\underline{\text { ratio }}$

The same quantity of concrete, which used in measuring slump value was used also to produce cube specimens for measuring the compression strengths of concrete mixture at ages 3, 7 and 28 days. Table (10) shows the results of compressive strength at different 
percentage values of $\mathrm{T} 1$, commercial admixtures and reduction of water / cement ratio. The commercial admixture has the same behavior as $\mathrm{T} 1$ but by fewer values.

Table (10) Relation between compressive strength for different values of reduction of water / cement ratio.

\begin{tabular}{|c|c|c|c|c|c|c|}
\hline \multirow[t]{2}{*}{ Item } & \multicolumn{3}{|c|}{ Compressive Strength $\left(\mathrm{kg} / \mathrm{cm}^{2}\right)$} & \multirow{2}{*}{$\begin{array}{l}\text { Reduction of } \\
\text { water/ cement } \\
\text { ratio }\end{array}$} & \multirow{2}{*}{$\begin{array}{l}\text { Slump }(\mathrm{c} \\
\mathrm{m})\end{array}$} & \multirow[t]{2}{*}{ group } \\
\hline & at 3days & at 7days & at 28 days & & & \\
\hline $\begin{array}{l}\mathrm{M}(0.00 \% \\
\text { admix.T1) }\end{array}$ & 160 & 204 & 350 & - & 8.5 & - \\
\hline \multirow{2}{*}{$\begin{array}{l}\text { M1 (0.1\% } \\
\text { admix.T1) }\end{array}$} & 203 & 240 & 385 & $5 \%$ & 8.1 & $\mathrm{E}$ \\
\hline & 207 & 249 & 390 & $13 \%$ & 8.4 & $\mathrm{~F}$ \\
\hline \multirow{2}{*}{$\begin{array}{l}\text { M2 }(0.25 \% \\
\text { admix.T1) }\end{array}$} & 216 & 254 & 394 & $5 \%$ & 8.4 & $\mathrm{E}$ \\
\hline & 224 & 264 & 400 & $13 \%$ & 8.2 & $\mathrm{~F}$ \\
\hline \multirow{4}{*}{$\begin{array}{l}\text { M2 (0.50\% } \\
\text { admix.T1) }\end{array}$} & 230 & 268 & 405 & $5 \%$ & 7.4 & $\mathrm{E}$ \\
\hline & 232 & 280 & 419 & $13 \%$ & 7.2 & $\mathrm{E}$ \\
\hline & 237 & 283 & 425 & $15 \%$ & 7.2 & $\mathrm{~F}$ \\
\hline & 240 & 290 & 435 & $25 \%$ & 8.2 & $\mathrm{~F}$ \\
\hline \multirow{4}{*}{$\begin{array}{l}\text { M2 (0.75\% } \\
\text { admix.T1) }\end{array}$} & 245 & 281 & 421 & $5 \%$ & 6.8 & $E$ \\
\hline & 250 & 288 & 430 & $13 \%$ & 7.4 & $E$ \\
\hline & 259 & 290 & 435 & $20 \%$ & 7.8 & $\mathrm{~F}$ \\
\hline & 271 & 298 & 450 & $30 \%$ & 8.4 & $\mathrm{~F}$ \\
\hline
\end{tabular}

From the above results the additive admixture $\mathrm{T} 1$ percentage $0.1 \%$ of cement weight to concrete gives the best results of compressive strength ( class F) according to ASTM494.

5- Conclusion

1- The optimum additive admixture diethanol amine and fatty acid values was $0.1 \%$ which realized:-

a- Increase in compressive strength by $10 \%$ after 28 days.

b- Increase in workability.

c- Reduction of water-cement ratio was greater than $12 \%$. d- Decrease the initial setting time.

2- According to ASTM C-494, this admixture T1 can be considered as $\mathrm{F}$ group.

3- The admixtureT 1 works as superplasticizer when the admixture ratio arrived to $0.75 \%$.

4- The admixture diethanol amine and fatty acid improved the mechanical properties of concrete by $20 \%$ more than the commercial admixture. 
5- The new admixture have not chloride ions which improve the corrosion resistance.

\section{6- Reference}

1- http:www. Cement. Org.

2- V.S.Ramachandran, il cement, 1, 13 (1986).

3- S.H. Tantawi and I.Z.Selim, $21^{\text {th }}$ Annual Conference "Corrosion Problems in Industry" 17

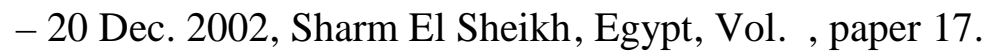

4- Tayfun Altug Soylev, Ciaran McNally Mark Richardson "Effectiveness of amino alcohol based surface - applied corrosion inhibitors in chloride - contaminated concrete cement \& concrete Research 37

( 2007) pp.972,977.

5- Egyptian standard specification number 4756-1/2007.

6- Standard specifications of national company for cement 2010.

7- Dr. khalaf mohamed Abdel moaty "Effect of protective coating local defects on corrosion rate of reinforcing steel bars" scientific bulletin vol. 40 No. 4, 31 December 2005.

8- E.A. Nasr, M.M. Abdel wahab and M.A. Khalaf " Corrosion Resistance of reinforced concrete using different protection Methods" Tenth international colloquium on structural and Geotechnical Engineering April 2003.

9- ACI 318-08 Building Code Requirements for Structural Concrete and Commentary , 2008 Edition.

10- Standard specification for chemical Admixtures for concrete ap proved May 1, 2005 united states pp $274-283$. 